УДК: 657.658.115

JEL Classification: M 41

H. С. СТРУК,

кандидат економічних наук, дочент кафедри обліку і аудиту,

Львівський національний університет імені Івана Франка;

Г. B. $P A K$,

асистент кафедри обліку і аудиту, Львівський національний університет імені Івана Франка

\title{
Особливості застосування прийомів бухгалтерського обліку до процесу використання фінансових ресурсів у бюджетних установах
}

Охарактеризовано прийоми бухгалтерського обліку для відображення операчій із використання фінансових ресурсів бюджетними установами. Продемонстровано взаємозв 'язок між прийомами первинного спостереження, вартісного вимірювання, поточного групування та реєстрації облікової інформації, з одного боку, та підсумковим узагальненням інформації в бухгалтерському обліку, з іншого. Розкрито взаємозв 'язок між прийомами обліку використання фінансових ресурсів бюджетними установами та застосуванням прочедурно-адитивного підходу.

Ключові слова: баланс, бюджетна установа, документування, звітність, інвентаризація, калькулювання, оцінка, подвійний запис, прийоми бухгалтерського обліку, рахунки обліку, фінансові ресурси.

Постановка проблеми. Прийоми бухгалтерського обліку, разом зі способами та процедурами, у визначеній послідовності та взаємозв'язку, формують бухгалтерський процес та прописуються в обліковій політиці на підприємствах, в установах та організаціях. Постійна мінливість законодавчої бази щодо методики здійснення облікових процедур та методів обліку спонукає до пошуку наукових обгрунтувань та їх прикладного застосування в обліковій діяльності суб'єктів господарювання.

Набирають чинності нові положення бухгалтерського обліку для бюджетних установ та впроваджується оновлений План рахунків бухгалтерського обліку в державному секторі [18], а також Закон України "Про внесення змін до Закону України «Про бухгалтерський облік та фінансову звітність в Україні» щодо удосконалення деяких положень “№ 2164-19 від 05.10.2017 р., в якому прописано зміни, пов’язані $з$ оновленням підходів до документування господарських операцій та удосконаленням наявних бухгалтерських положень [17].

Очевидно, що нововведення останнього часу потребують з'ясування особливостей застосування прийомів бухгалтерського обліку процесу використання фінансових ресурсів бюджетними установами.

Аналіз останніх досліджень і публікацій. Такий аналіз вказує на широкий спектр досліджень прийомів бухгалтерського обліку. Зокрема, М. В. Корягін широко аналізує такі прийоми як “первинне та зведене документування; первинне оцінювання та оцінювання на дату балансу; планове та звітне калькулювання; балансове, позабалансове, небалансове ведення рахунків; процедури підготовки фінансової, управлінської та податкової звітності” [8, с. 109]. Ю. О. Івахів розглядає звітність як “відображення економічних явищ, процесів, результатів господарської діяльності підприємств і їх науково-практичного пізнання зацікавленими суб'єктами" [4, с. 77]. Т. О. Тичук, характеризуючи прийоми бухгалтерського обліку, акцентує увагу на місці та ролі облікової оцінки в господарській діяльності підприємства, зазначаючи, що іiі “.... сутність полягає в перерахунку натуральних та трудових характеристик об'єктів обліку у вартісні відповідно до встановлених пропорцій” [13, с. 101], а В. О. Осмятченко досліджує облікові перспективи електронного документування, адже “первинний

(C) Н. С. Струк, Г. В. Рак, 2018 
документ може складатися або в бухгалтерії, або на робочих місцях облікових працівників за допомогою обчислювальної техніки < .. > реєструється в комп'ютерному журналі реєстрації первинних документів, а проведення додаються до електронного журналу операцій” [11, с. 104]. Незважаючи на дещо абстрактний характер результатів тематичних досліджень, більшість із них торкаються прийомів бухгалтерського обліку господарських операцій комерційних структур.

Формулювання мети і завдань статті. Метою дослідження є 3'ясування особливостей застосування сучасних прийомів бухгалтерського обліку у процесі використання фінансових ресурсів бюджетними установами та розкриття взаємозв'язку між обліковими принципами та методами обліку. Для досягнення поставленої мети вирішуються такі завдання: розкриття змісту бухгалтерського процесу та його методичних елементів; розгляд процедурно-адитивного підходу до обгрунтування сутності прийомів бухгалтерського обліку; характеристика прийомів бухгалтерського обліку у процесі використання фінансових ресурсів бюджетними установами; систематизація та порівняння вітчизняних досліджень про принципи та методи бухгалтерського обліку з аналогічними зарубіжними дослідженнями, що відображатиме рівень адаптації українського законодавства до міжнародних стандартів обліку та звітності.

Виклад основного матеріалу дослідження. Бухгалтерський процес, як процес виконання бухгалтерських процедур із застосуванням взаємоузгоджених інструментів, прийомів та способів у певній послідовності та взаємозалежності (рис. 1), відбувається від початку реєстрації господарських операцій до складання звітності.

Під час організації та виконання бухгалтерського процесу належна увага надається прийомам, методам та принципам бухгалтерського обліку. Правильна організація бухгалтерського процесу щодо використання фінансових ресурсів у бюджетних установах $\epsilon$ важливим чинником підвищення ефективності їх діяльності, адже вона сприяє не лише отриманню достовірної, своєчасної та неупередженої інформації, а й порядку ведення бухгалтерського обліку та системі внутрішнього і зовнішнього контролю використання бюджетних коштів.

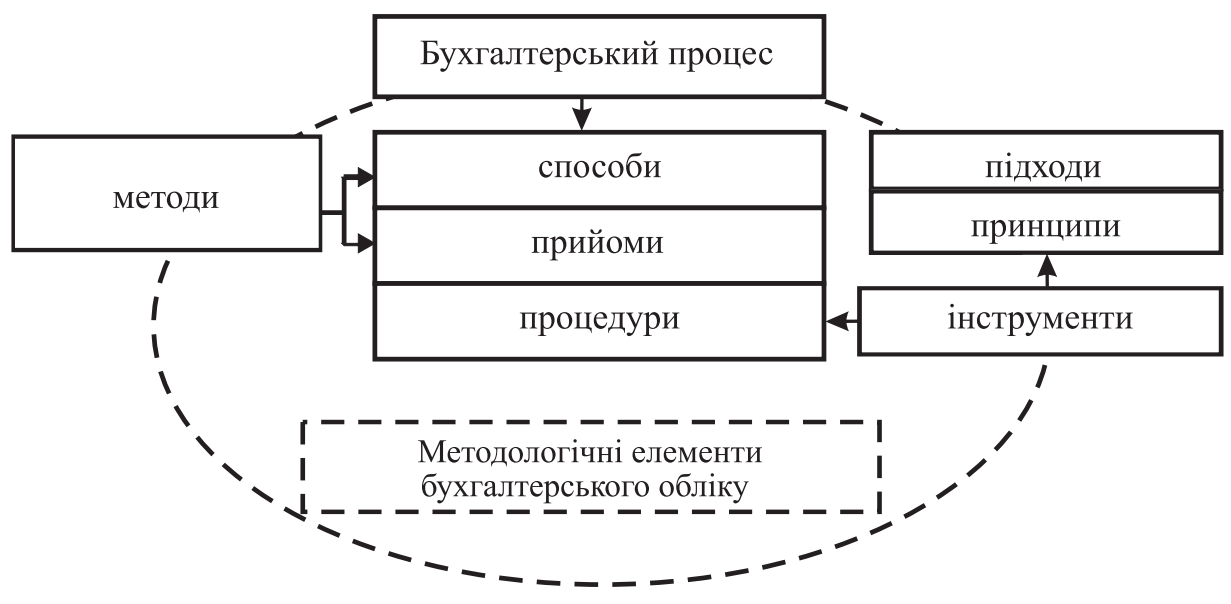

Рис. 1. Складові бухгалтерського процесу

Джерело: розроблено авторами за $[1 ; 6]$

Облікові прийоми - основа раціональної організації обліку процесу використання фінансових ресурсів у бюджетних установах.

Такими прийомами вважаються: первинне спостереження (документування та інвентаризація), вартісне вимірювання (оцінка та калькуляція), поточне групування та реєстрація інформації (рахунки та подвійний запис), підсумкове узагальнення інформації (баланс і звітність). В сукупності вони найчастіше відомі як елементи методу бухгалтерського обліку. Водночас, у зв'язку зі змінами українського законодавства та розвитком інформаційних технологій у світі, реформуються деякі 
прийоми бухгалтерського обліку, зокрема спостерігаються зміни у документуванні, звітності та переліку рахунків бухгалтерського обліку діяльності бюджетних установ.

Розглядаючи прийоми бухгалтерського обліку загалом, варто підкреслити популярність адитивного підходу та його визнання у наукових колах $[6 ; 12 ; 15]$. Відповідно до цього підходу всі облікові прийоми розглядаються як єдине ціле (метод бухгалтерського обліку) та окремо (елементи методу бухгалтерського обліку). Це документування та інвентаризація, оцінка та калькулювання, рахунки та подвійний запис, а також баланс і звітність, що стосуються всіх аспектів обліку процесу використання фінансових ресурсів бюджетними установами.

Варто згадати й менш поширений процедурний підхід, відповідно до якого всі прийоми бухгалтерського обліку розглядаються як поетапні облікові процедури $[6 ; 12]$. Так, процес обліку використання фінансових ресурсів бюджетними установами починається з первинного спостереження фактів до вартісного вимірювання обмінних та необмінних операцій бюджетних установ, яке передує поточному групуванню та реєстрації релевантної інформації в обліку й завершує такий обліковий цикл підсумковим узагальненням інформації про факти використання фінансових ресурсів бюджетною установою (рис. 2).

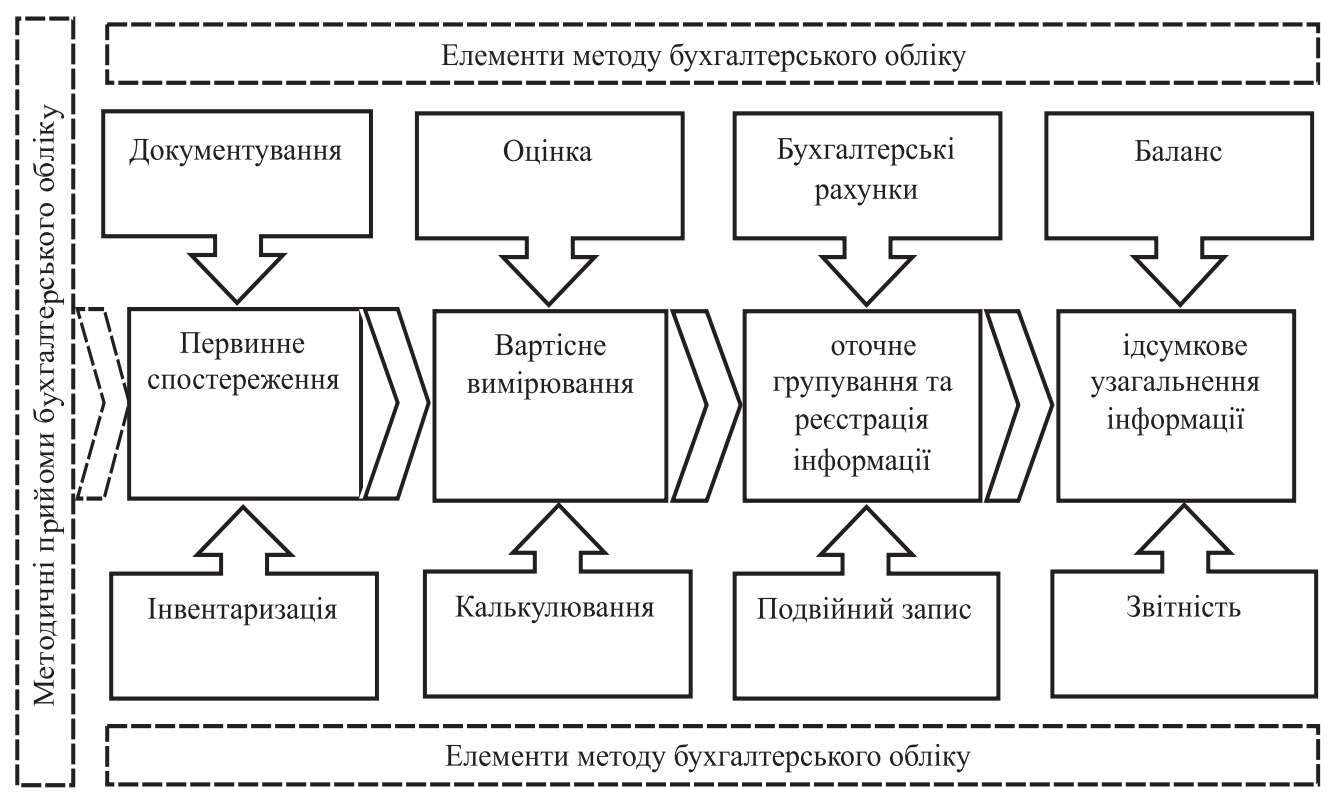

\section{Рис. 2. Процедурно-адитивний підхід до прийомів бухгалтерського обліку використання фінансових ресурсів бюджетними установами}

Джерело: розроблено авторами за [6; 12; 15]

Так, первинне спостереження за фактами використання фінансових ресурсів бюджетними установами є початковим етапом ведення його обліку. За допомогою документування у бюджетній установі здійснюється первинне суцільне відображення фінансових ресурсів в обліку їх використання. На кожну операцію або групу однорідних операцій використання фінансових ресурсів складають підтверджувальний документ, який є носієм первинної облікової інформації та слугує надалі підставою для реєстрації фактів використання фінансових ресурсів за рахунками бухгалтерського обліку бюджетної установи [11, с. 99].

При цьому процес обліку документування фактів використання фінансових ресурсів бюджетними установами у системі казначейського обслуговування тісно переплетений із самим бюджетним процесом. Так, фінансовий підрозділ бюджетної установи здійснює економічні розрахунки для проекту кошторису, тобто враховуються потреби та норми видатків для утримання бюджетної установи. Використан- 
ня фінансових ресурсів бюджетними установами здійснюється лише на підставі затвердженого в установленому бюджетним законодавством порядку, кошторису бюджетної установи [10, с. 63-64]. Прийомом документування у меморіальноордерній формі обліку передбачені відповідні форми первинних та зведених документів для діяльності бюджетних установ із дотриманням вимог законодавства щодо електронних документів та електронного документообігу в Україні.

Застосування прийому інвентаризації у первинному спостереженні за процесом використання фінансових ресурсів бюджетними установами передбачає періодичну перевірку фактичної наявності фінансових ресурсів і відповідних зобов'язань бюджетної установи, а також зіставлення отриманих даних про стан фінансових ресурсів із даними облікових показників, наступне їх уточнення у випадку виявлених розбіжностей на певну дату. Водночас проведення інвентаризації фактів використання фінансових ресурсів у бюджетній установі належить до основних способів контролю за її фінансово-розрахунковою дисципліною. Бюджетні установи складають окремі інвентаризаційні описи на фінансові ресурси, які перебувають у їх розпорядженні, з відповідним розподілом за обмінними та необмінними операціями [2, с. 170].

Після первинного облікового спостереження за використанням фінансових ресурсів у бюджетній установі відбувається їх вартісне вимірювання, яке реалізується в бухгалтерському обліку за допомогою їх оцінки та калькулювання. Результатом вартісного вимірювання $є$ подання їх у єдиному грошовому вимірнику. Єдиний грошовий вимірник фінансових ресурсів бюджетної установи дозволяє проводити реєстрацію кругообігу іï фінансових ресурсів з одночасним його контролем у системі бухгалтерських рахунків, облікових регістрах і звітності.

Зокрема, оцінка в обліку використання бюджетною установою фінансових ресурсів використовується як прийом грошового вимірювання фінансових ресурсів i джерел їх формування за обмінними чи необмінними операціями. Для формування облікової інформації про використання бюджетною установою фінансових ресурсів уся сукупність таких операцій оцінюється у гривнях, відповідно до Національних стандартів бухгалтерського обліку в державному секторі [3, с. 779], в тому числі за первісною вартістю. Практика казначейського обслуговування бюджетної системи України свідчить, що в основу оцінки використання фінансових ресурсів бюджетною установою покладено різні принципи оцінки касових та фактичних видатків: оцінка касових видатків бюджетних установ здійснюється в момент отримання фінансових ресурсів бюджетною установою; оцінка фактичних видатків бюджетних установ відбувається у момент їх визначення або нарахування [7, с. 78-83].

Калькулювання, як прийом вартісного вимірювання, передбачає групування витрат і визначення собівартості придбаних бюджетною установою матеріальних цінностей, виготовленої нею продукції, виконаних робіт і наданих послуг. Калькулювання обсягу використання бюджетною установою фінансових ресурсів складається на основі даних обліку витрат, що відносяться до калькуляційного об'єкта обліку і лежить в основі їх оцінки. Калькулювання дає змогу визначити фактичну собівартість використання бюджетною установою фінансових ресурсів у бухгалтерському обліку, а також обгрунтувати економічні розрахунки для проекту кошторису видатків бюджетної установи.

Наступним етапом обліку використання фінансових ресурсів бюджетними установами є поточне групування та реєстрація інформації про факти такого процесу. Так, за допомогою рахунків бухгалтерського обліку бюджетної установи здійснюється поточне групування та відображення в обліку фінансових ресурсів, їх джерел і фактів їх використання з контрольною метою. Рахунки дають змогу відобразити не лише стан фінансових ресурсів на початок і кінець бюджетного періоду, а й зміни фінансових ресурсів як об'єктів обліку в результаті їх використання бюджетною установою. Донедавна грошові кошти в касі бюджетної установи відображалися за субрахунками 301 “Каса в національній валюті” та 302 “Каса в іноземній валюті”, тоді як сьогодні для потреб обліку фінансових ресурсів бюджетної установи передбачено субрахунки 2211 "Готівка у національній валюті" та 2212 "Готівка в іноземній валюті". Окрім 
того, бюджетні установи з 2017 р. зобов'язані вести облік використання фінансових ресурсів на більш деталізованому рівні [19].

Варто зазначити, що застосування прийому подвійного запису дає змогу взаємопов'язати відображення обмінних та необмінних операцій на балансових рахунках бухгалтерського обліку бюджетної установи. Подвійний запис обумовлений подвійністю самих операцій використання фінансових ресурсів бюджетної установи, яка розкриває їх зміст і сутність. Очевидно, що всі зміни в портфелі бюджетних фінансових ресурсів мають два аспекти: збільшення і зменшення обсягу фінансових ресурсів, їх надходження та витрачання бюджетною установою, які компенсують один одного. Прийом подвійного запису є зручним інструментом для підготовки звітності про використання фінансових ресурсів бюджетної установи. Наприклад, бюджетна установа вирішує здійснити використання спонсорських внесків для розрахунків з іншими кредиторами. Для цього в обліку використання фінансових ресурсів бюджетної установи здійснюється відповідний подвійний запис:

Дт рах. 6415 "Розрахунки з іншими кредиторами"

Кт рах. 2311 "Поточні рахунки в банку".

Через те, що бюджетні установи визнані неприбутковими та утримуються коштом бюджету, для контролю видатків бюджетної установи передбачена їх бюджетна класифікація, в тому числі економічна. Односторонній запис фактів використання фінансових ресурсів бюджетної установи відповідно до кодів економічної класифікації видатків (КЕКВ) має важливе значення для здійснення обліку видатків будь-якої бюджетної установи, адже всі витрати фінансових ресурсів бюджетної установи плануються в кошторисі й відображаються в обліку та звітності бюджетної установи за КЕКВ [14, с. 284].

Насамкінець прийоми підсумкового узагальнення інформації про витрати бюджетної установи (баланс та звітність) передбачають узагальнення та передавання облікової інформації про використання фінансових ресурсів у бюджетній установі зовнішнім та внутрішнім користувачам [1, с. 110]. Наприклад, застосування такого облікового прийому як баланс уможливлює економічне групування в грошовій оцінці фінансових ресурсів бюджетної установи за їх складом і джерелами формування на певну дату. Фінансові ресурси бюджетної установи відображаються в балансі грошовим вимірником в двох частинах: одна показує, які фінансові ресурси бюджетна установа має в своєму розпорядженні, інша - з яких джерел ці фінансові ресурси надійшли в іiі розпорядження. Обидві частини балансу бюджетної установи є еквівалентними, оскільки в них відображаються одні й ті самі фінансові ресурси: з одного боку, за складом та розміщенням (фінансові ресурси в якості активів, а також витрати), а 3 іншого - за джерелами їх формування (фінансові ресурси в якості зобов'язань та капіталу, а також доходи).

Бюджетні установи відображають інформацію про стан використання фінансових ресурсів у звітності відповідно до Порядку складання фінансової та бюджетної звітності розпорядниками та одержувачами бюджетних коштів. Так, результати використання фінансових ресурсів бюджетної установи відображаються та деталізуються у розрізі фінансової та бюджетної звітності розпорядників та одержувачів бюджетних коштів за відповідний звітний період (місяць, квартал, рік) із дотриманням низки основних принципів обліку та звітності в Україні.

Дотримання принципів та застосування методів бухгалтерського обліку відіграє важливу роль у здійсненні облікових процедур. Приведення вітчизняного методичного забезпечення бухгалтерського обліку до рівня світових вимог та стандартів зумовлює потребу у систематизації принципів та методів бухгалтерського обліку (табл. 1).

Як видно з табл. 1, міжнародне методичне забезпечення обліку відрізняється від вітчизняного, а традиційні елементи методу доповнені за кордоном аналітичними, статистичними та економіко-математичними методами. Що стосується порівняння вітчизняних та міжнародних облікових принципів, то законодавством України не враховано такі як надійність і точність, імпаритет, ясність і зрозумілість, суттєвість та унікальність. 
Таблиия 1

Узагальнені тлумачення принципів і методів бухгалтерського облік

\begin{tabular}{|c|c|}
\hline Принципи бухгалтерського обліку & Методи бухгалтерського обліку \\
\hline 1 & 2 \\
\hline \multicolumn{2}{|c|}{ вітчизняна практика } \\
\hline $\begin{array}{l}\text { *Обачність - застосування в бухгалтер- } \\
\text { ському обліку методів оцінки, які повинні } \\
\text { запобігати заниженню оцінки зобов'язань } \\
\text { та витрат і завищенню оцінки активів і до- } \\
\text { ходів підприємства }\end{array}$ & $\begin{array}{l}\text { Оцінка - спосіб грошового вимірювання } \\
\text { об'єктів бухгалтерського обліку. }\end{array}$ \\
\hline $\begin{array}{l}\text { Повне висвітлення - фінансова звітність } \\
\text { повинна містити всю інформацію про } \\
\text { фактичні та потенційні наслідки господар- } \\
\text { ських операцій і подій, здатних вплинути } \\
\text { на рішення, що приймаються на її основі. }\end{array}$ & $\begin{array}{l}\text { Iнвентаризаиія - спосіб виявлення фактич- } \\
\text { ної наявності і стану господарських засобів, } \\
\text { коштів підприємства та джерел їх утворення } \\
\text { на певну дату. }\end{array}$ \\
\hline $\begin{array}{l}\text { Автономність - кожне підприємство роз- } \\
\text { глядається як юридична особа, відокремлена } \\
\text { від ії власників, у зв'язку з цим особисте } \\
\text { майно та зобов'язання власників не пови- } \\
\text { нні відображатися у фінансовій звітності } \\
\text { підприємства. }\end{array}$ & $\begin{array}{l}\text { Документування - спосіб первинної ре- } \\
\text { єстрації господарських операцій для су- } \\
\text { цільного спостереження за господарськими } \\
\text { процесами та безперервного відображення } \\
\text { в поточному обліку. }\end{array}$ \\
\hline $\begin{array}{l}\text { Послідовність - постійне (із року в рік) } \\
\text { застосування підприємством обраної об- } \\
\text { лікової політики. Зміна облікової політики } \\
\text { можлива у випадках, передбачених НП(С) } \\
\text { БО, і повинна бути обгрунтована та роз- } \\
\text { крита у фінансовій звітності. }\end{array}$ & $\begin{array}{l}\text { Калькулювання-спосіб групування витрат і } \\
\text { визначення собівартості придбаних матері- } \\
\text { альних цінностей, виготовленої продукції, } \\
\text { виконаних робіт та наданих послуг. }\end{array}$ \\
\hline $\begin{array}{l}\text { Безперервність - оцінка активів та зобов'я- } \\
\text { зань підприємства здійснюється виходячи з } \\
\text { припущення, що його діяльність триватиме } \\
\text { далі. }\end{array}$ & \multirow{2}{*}{$\begin{array}{l}\text { Рахунки - спосіб економічного групування } \\
\text { та оперативного контролю активів, капіталу, } \\
\text { зобов'язань і господарських операцій, іх } \\
\text { наявності та змін. Використання рахунків } \\
\text { дозволяє групувати інформацію, відображе- } \\
\text { ну у первинних документах за економічно } \\
\text { однорідними ознаками, для її відображення } \\
\text { у фінансовій звітності. }\end{array}$} \\
\hline $\begin{array}{l}\text { Нарахування та відповідність доходів і ви- } \\
\text { mрат- для визначення фінансового резуль- } \\
\text { тату звітного періоду необхідно порівняти } \\
\text { доходи звітного періоду з витратами, що } \\
\text { були здійснені для отримання цих доходів. } \\
\text { При цьому доходи і витрати відображають- } \\
\text { ся в бухгалтерському обліку та фінансовій } \\
\text { звітності в момент їх виникнення, незалежно } \\
\text { від дати надходження або сплати грошових } \\
\text { коштів. }\end{array}$ & \\
\hline $\begin{array}{l}\text { Превалювання сутності над формою - опе- } \\
\text { рації обліковуються відповідно до їх сутнос- } \\
\text { ті, а не лише виходячи з юридичної форми. }\end{array}$ & $\begin{array}{l}\text { Подвійний запис - відображення у бухгал- } \\
\text { терському обліку кожної господарської опе- } \\
\text { рації за дебетом одного і кредитом іншого } \\
\text { рахунку на одну й ту саму суму. }\end{array}$ \\
\hline $\begin{array}{l}\text { *Історична (фактична) собівартість - } \\
\text { пріоритетною є оцінка активів виходячи } \\
\text { з витрат на їх виробництво та придбання. }\end{array}$ & $\begin{array}{l}\text { Баланс-спосіб групування і відображення } \\
\text { наявності й стану господарських засобів } \\
\text { підприємства за складом і розміщенням та } \\
\text { джерелами утворення на певну дату в уза- } \\
\text { гальненому вартісному вимірнику. }\end{array}$ \\
\hline $\begin{array}{l}\text { Єдиний грошовий вимірник - вимірювання } \\
\text { та узагальнення всіх господарських опера- } \\
\text { цій підприємства у його фінансовій звітнос- } \\
\text { ті здійснюються в єдиній грошовій одиниць. }\end{array}$ & \multirow{2}{*}{$\begin{array}{l}\text { 3вітність-система підсумкових даних про } \\
\text { майнове і фінансове становище організаціі } \\
\text { та про результати її господарської діяльнос- } \\
\text { ті на основі даних бухгалтерського обліку } \\
\text { за встановленими формами. }\end{array}$} \\
\hline $\begin{array}{l}\text { * Періодичність - можливість розподілу ді- } \\
\text { яльності підприємства на певні періоди часу } \\
\text { з метою складання фінансової звітності. }\end{array}$ & \\
\hline
\end{tabular}




\begin{tabular}{|c|c|}
\hline & Продовження табл. 1 \\
\hline 1 & 2 \\
\hline \multicolumn{2}{|c|}{ зарубіжсна практика } \\
\hline $\begin{array}{l}\text { Надійність i mочність - інформація про } \\
\text { фінансовий стан та результати діяльності } \\
\text { повинна бути достовірною. }\end{array}$ & $\begin{array}{l}\text { Метод моментів } і \text { періодів - полягає у } \\
\text { представленні всіх фактичних даних щодо } \\
\text { майнового стану суб’єкта господарювання } \\
\text { у кожному звітному періоді та на будь-яку } \\
\text { дату. }\end{array}$ \\
\hline $\begin{array}{l}\text { Iмnаритет - під час обліку та оцінки майна } \\
\text { та зобов'язань перевага віддається відобра- } \\
\text { женню втрат, а не вигод. }\end{array}$ & $\begin{array}{l}\text { Метод групування - передбачає системати- } \\
\text { зацію та представлення інформації у фінан- } \\
\text { совій звітності відповідних форм. }\end{array}$ \\
\hline $\begin{array}{l}\text { Ясність і зрозумілість-фінансова звітність } \\
\text { має бути зрозумілою для усіх користувачів } \\
\text { інформації, а не лише кваліфікованому } \\
\text { фахівцеві. }\end{array}$ & $\begin{array}{l}\text { Економічнийметод-полягає у трактуванні } \\
\text { усіх економічних подій та явищ із точки } \\
\text { зору підприємства, передбачає ведення } \\
\text { обліку всіх фактів господарського життя. }\end{array}$ \\
\hline $\begin{array}{l}\text { Cymmєвість - кожен важливий момент має } \\
\text { бути врахований у бухгалтерському обліку } \\
\text { та оприлюднений у фінансовій звітності. }\end{array}$ & $\begin{array}{l}\text { Економіко-математичне та статистичне } \\
\text { моделювання - швидкий перехід на обро- } \\
\text { блення даних інформаційно-комп’ютерними } \\
\text { системами. }\end{array}$ \\
\hline $\begin{array}{l}\text { Унікальність - передбачає, що основою } \\
\text { складання різних видів звітності є сис- } \\
\text { тема бухгалтерського обліку як основне } \\
\text { інформаційне джерело, щоб не допустити } \\
\text { викривлення інформації у звітності. }\end{array}$ & $\begin{array}{l}\text { Аналітичні методи - методи додаткового } \\
\text { аналізу фінансово-господарської діяльності } \\
\text { суб’єкта господарювання для отримання } \\
\text { покращеної інформації, більш зрозумілої } \\
\text { та доступної. }\end{array}$ \\
\hline
\end{tabular}

* Принципи обачності, історичної собівартості, періодичності будуть вилучені з 01.01.2018 року згідно зі змінами, внесеними до ЗУ “Про бухгалтерський облік та фінансову звітність в Україні".

Джерело: розроблено авторами за $[1$, с. $117 ; 16]$

Для визначення доцільності запровадження таких принципів та методів у вітчизняну практику слід детально їх проаналізувати та врахувати особливості українського законодавства, процесів економічного розвитку, інформаційних систем і технологій в обліковій практиці тощо.

Висновки. Таким чином, окремі прийоми обліку використання фінансових ресурсів бюджетними структурами, а також принципи і методи є тісно взаємопов'язаними і в сукупності становлять методичне забезпечення бухгалтерського обліку в бюджетних установах. Ефективне функціонування бюджетних установ неможливе без врахування сучасних прийомів бухгалтерського обліку процесу використання фінансових ресурсів.

3'ясування особливостей сучасних прийомів обліку та розкриття взаємозв'язку між обліковими принципами та методами дало змогу запропонувати процедурноадитивний підхід до тлумачення прийомів бухгалтерського обліку процесу використання фінансових ресурсів бюджетними установами, що уможливлює подальше вдосконалення теоретичного підгрунтя бухгалтерського обліку бюджетних установ у період його реформування.

Перспективами подальших досліджень $€$ пошук можливих напрямів покращення процесу автоматизації прийомів бухгалтерського обліку використання фінансових ресурсів у бюджетних установах.

\section{Список використаних джерел}

1. Корягін М. В. Концептуальний розвиток методології бухгалтерського обліку: моногр. Львів: ЛКА, 2015. 239 с.

2. Букало Н. А. Інвентаризація як умова для складання фінансової звітності. Економічний аналіз: зб. наук. пр. / Редкол.: В. А. Дерій та ін. Тернопіль: ТНЕУ, 2016. T. 23. C. $167-173$. 
3. Дорошенко О. О. Оцінка бюджетних установ у методології бухгалтерського обліку: сучасні підходи та новації. Глобальні та національні проблеми економіки. Миколаїв, 2016. Вип. 9. С. 776-780.

4. Івахів Ю. О. Фінансова звітність та елементи методу бухгалтерського обліку // Інвестиції: практика та досвід. 2011. № 16. С. 76-77.

5. Ільченко О. О. Теоретико-методологічні аспекти проведення інвентаризації // Бухгалтерський облік, аналіз та аудит: проблеми теорії, методології, організації. 2012. № 2(9). С. 48-54.

6. Канцедал Н. А. Адитивний і процедурний підходи як способи пізнання в методології наукових досліджень обліку // Облік і фінанси. 2016. № 1(71). С. 27-31.

7. Карпенко Н. Г. Завдання та порядок відображення в обліку видатків бюджетних установ // Наукові праці ПДАА, 2013.Т. 3. № 2. С. 78-83.

8. Корягін М. В. Удосконалення методології бухгалтерського обліку // Вісник Львівської комерційної академії. 2013. Вип. 43. С. 107-113.

9. Кузнецова С. А. Організація бухгалтерського обліку за стадіями облікового процесу // Європейський вектор економічного розвитку. 2015. № 2. С. 107-118.

10. Норд Г. Л. Особливості фінансування та казначейського обслуговування бюджетних установ на прикладі ВНЗ // Наукові праці. 2011. Вип. 149. Т. 161. С. 61-66.

11. Осмятченко В. О. Електронне документування у бухгалтерському обліку // Вісник Київського національного торговельно-економічного університету. 2013. № 2. C. $98-108$.

12. Скрипник М. І. Елементи методу бухгалтерського обліку як складові системи бухгалтерського обліку: наукові дискусії та протиріччя // Бухгалтерський облік, аналіз та аудит: проблеми теорії, методології, організації. 2012. Вип. 2(9). С. 197-204.

13. Тичук Т. О. Місце та роль оцінки як елементу методу бухгалтерського обліку за різними стадіями облікового циклу підприємства // Молодий вчений. 2015. № 5(2). C. $101-104$.

14. Юрченко О. Б. Організація обліку видатків бюджетних установ за новою економічною класифікацією та їх відображення у звітності // Науковий вісник НЛТУ України. Львів, 2013. Вип. 23.15. С. 283-289.

15. Яцунська О. С. Сутність оцінки як елемента метода бухгалтерського обліку: сучасні підходи до тлумачення // Вісник соціально-економічних досліджень. 2013. Вип. 4. C. 381-386.

16. Про бухгалтерський облік та фінансову звітність в Україні: закон України від 16.07.1999 p. № 996-XIV. URL: http://zakon4.rada.gov.ua/laws/show/996-14

17. Про внесення змін до Закону України "Про бухгалтерський облік та фінансову звітність в Україні" щодо удосконалення деяких положень: закон України від 05.10.2017 p. № 2164-19. URL: http://zakon2.rada.gov.ua/laws/show/2164-19

18. План рахунків бухгалтерського обліку в державному секторі, затверджений наказом Мінфіну від 31.12.2013 p. № 1203. URL: http://zakon2.rada.gov.ua/laws/show/ z0161-14

19. Гапоненко Л. В. Новий План рахунків: переносимо залишки/ Бюджетна бухгалтерія. 2017. URL: https://buhgalter.com.ua/articles/buhgalterskiy-oblik/noviy-plan-rahunkivperenosimo-zalishki/

\section{References}

1. Koriahin M. V. (2015). Kontseptualnyi rozvytok metodolohii bukhhalterskoho obliku [Conceptual development of the accounting methodology]. Lviv: LKA [in Ukrainian].

2. Bukalo N. A. (2016). Inventaryzatsiia yak umova dlia skladannia finansovoi zvitnosti. Ekonomichnyi analiz [Inventory: a condition for making financial reporting]. V. A. Derii et al. (eds.). Ternopil: TNEU. Vol. 23. P. 167-173 [in Ukrainian].

3. Doroshenko O. O. (2016). Otsinka biudzhetnykh ustanov u metodolohii bukhhalterskoho obliku: suchasni pidkhody ta novatsii [Valuation of budgetary institutions in the accounting methodology]. Hlobalni ta natsionalni problemy ekonomiky - Global and national problems of economics, 9. 776-780 [in Ukrainian].

4. Ivakhiv Yu. O. (2011). Finansova zvitnist ta elementy metodu bukhhalterskoho obliku [Financial reporting and elements of the accounting method]. Investytsii: praktyka ta dosvid - Investment: practices and experiences, 16, 76-77 [in Ukrainian]. 
5. Ilchenko O. O. (2012). Teoretyko-metodolohichni aspekty provedennia inventaryzatsii [Theoretical and methodological aspects of invenstory]. Bukhhalterskyi oblik, analiz ta audyt: problemy teorii, metodolohii, orhanizatsii - Accounting, analysis and audit: problems of theory, methodology, organization, 2(9), 48-54 [in Ukrainian].

6. Kantsedal N. A. (2016). Adytyvnyi i protsedurnyi pidkhody yak sposoby piznannia v metodolohii naukovykh doslidzhen obliku [Aditive and procedural approach: the cognitive ways in the methodology of scientific studies of accounting]. Oblik i finansy - Accounting and finance, 1(71), 27-31 [in Ukrainian].

7. Karpenko N. H. (2013). Zavdannia ta poriadok vidobrazhennia v obliku vydatkiv biudzhetnykh ustanov [Recording of expenditures in budgetary institutions: the objectives and procedures]. Naukovi pratsi PDAA. - Scientific works of Poltava State Agrarian Academy, 3(2). 78-83 [in Ukrainian].

8. Koriahin M. V. (2013). Udoskonalennia metodolohii bukhhalterskoho obliku [Improving the methodology of accounting]. Visnyk Lvivskoi komertsiinoi akademii - Bulletin of Lviv Commercial Academy, 43, 107-113 [in Ukrainian].

9. Kuznetsova S. A. (2015). Orhanizatsiia bukhhalterskoho obliku za stadiiamy oblikovoho protsesu [Organization of accounting by phase of accounting process]. Yevropeiskyi vektor ekonomichnoho rozvytku - The European vector of economic development, 2, $107-118$ [ in Ukrainian].

10. Nord H. L. (2011). Osoblyvosti finansuvannia ta kaznacheiskoho obsluhovuvannia biudzhetnykh ustanov na prykladi VNZ [Perculiarities of financing and treasury services of budgetary institutions by case of HEEs]. Naukovi pratsi - Scientific works, 149 (161), 61-66 [in Ukrainian].

11. Osmiatchenko V. O. (2013). Elektronne dokumentuvannia u bukhhalterskomu obliku [Electronic documenting in accounting]. Visnyk Kyivskoho natsionalnoho torhovelnoekonomichnoho universytetu - Bulletin of National University of Trade and Economics, 2, 98-108 [in Ukrainian].

12. Skrypnyk M. I. (2012). Elementy metodu bukhhalterskoho obliku yak skladovi systemy bukhhalterskoho obliku: naukovi dyskusii ta protyrichchia [Elements of the accounting method: the components of the accounting system]. Bukhhalterskyi oblik, analiz ta audyt: problemy teorii, metodolohii, orhanizatsii - Accounting, analysis and audit: problems of theory, methodology, organization, 2(9), 197-204 [in Ukrainian].

13. Tychuk T. O. (2015). Mistse ta rol otsinky yak elementu metodu bukhhalterskoho obliku za riznymy stadiiamy oblikovoho tsyklu pidpryiemstva [The place and role of valuation as an element in the method of accounting by phase of accounting cycle in an enterprise]. Molodyi vchenyi - Young scientist, 5(2), 101-104 [in Ukrainian].

14. Iurchenko O. B. (2013). Orhanizatsiia obliku vydatkiv biudzhetnykh ustanov za novoiu ekonomichnoiu klasyfikatsiieiu ta yikh vidobrazhennia u zvitnosti [Organization of the accounting of expenditures in budgetary institutions by the new economic classification and their recording in reports]. Naukovyi visnyk NLTU Ukrainy - Scientific Bulletin of Ukrainian National Forestry University, 23.15, 283-289 [in Ukrainian].

15. Iatsunska O. S. (2013). Sutnist otsinky yak elementa metoda bukhhalterskoho obliku: suchasni pidkhody do tlumachennia [The essence of valuation as an element in the accounting method: modern approaches to the interpretation]. Visnyk sotsialnoekonomichnykh doslidzhen - Bulletin of Social and Economic Studies, 4, 381-386 [in Ukrainian].

16. Pro bukhhalterskyi oblik ta finansovu zvitnist v Ukraini: zakon Ukrainy vid 16.07.1999 r. № 996-XIV [Accounting and financial reporting in Ukraine: the law of Ukraine from 16.07.1999 No 996-XIV]. URL: http://zakon4.rada.gov.ua/laws/show/996-14 [in Ukrainian].

17. Pro vnesennia zmin do Zakonu Ukrainy "Pro bukhhalterskyi oblik ta finansovu zvitnist v Ukraini" shchodo udoskonalennia deiakykh polozhen: zakon Ukrainy vid 05.10.2017 r. № 2164-19 [Amendments to the Law of Ukraine "Accounting and financial reporting in Ukraine", for the improvement of some provisions: the law of Ukraine from 05.10.2017 No 2164-19]. URL: http://zakon2.rada.gov.ua/laws/show/2164-19 [in Ukrainian].

18. Plan rakhunkiv bukhhalterskoho obliku v derzhavnomu sektori, zatverdzhenyi nakazom Minfinu vid 31.12.2013 r. № 1203 [The plan of accounting in the public sector, approved 
by the decree of the Ministry of Finance from 31.12.2013 No 1203]. URL: http://zakon2. rada.gov.ua/laws/show/z0161-14 [in Ukrainian].

19. Haponenko L. V. (2017). Novyi Plan rakhunkiv: perenosymo zalyshky [The new plan of accounts: carrying-over the balances]. Biudzhetna bukhhalteriia - Budget accounting. URL: https://buhgalter.com.ua/articles/buhgalterskiy-oblik/noviy-plan-rahunkivperenosimo-zalishki/

H. С. СТРУК, кандидат экономических наук, доиент кафедры учета и аудита Львовский национальный университет имени Ивана Франко; Г. В. $P A K$, ассистент кафедры учета и аудита, Львовский национальный университет имени Ивана Франко

\section{Особенности применения приемов бухгалтерского учета к процессу использования финансовых ресурсов в бюджетных учреждениях}

Охарактеризованы приемы бухгалтерского учета для отражения операчий по использованию финансовых ресурсов бюджетными учреждениями. Продемонстрирована взаимосвязь между приемами первичного наблюдения, стоимостного измерения, текущей группировки и регистрачии учетной информации, с одной стороны, и итоговым обобщением информачии в бухгалтерском учете, с другой. Раскрыта взаимосвязь между приемами учета использования финансовых ресурсов бюджетными учреждениями и применением процедурно-аддитивного подхода.

Ключевые слова: баланс, бюджетное учреждение, документирование, отчетность, инвентаризачия, калькулирование, оченка, двойная запись, приемь бухгалтерского учета, счета учета, финансовые ресурсы.

N. S. STRUK,

PhD (Economics), Associate Professor of Audit and Accounting Department, Ivan Franko National University of Lviv;

G. V. RAK, Assistant of Audit and Accounting Department,

Ivan Franko National University of Lviv

\section{Using Financial Resources in Budgetary Institutions: Advanced Accounting Techniques}

Accounting techniques, methods and procedures set in the necessary sequence form the accounting process, and they are fixed in the accounting policy at companies, institutions and organizations. The volatility of the legal framework pertaining to accounting procedures and accounting methods causes the need for new scientific developments in this field and their applications in the accounting practices of business entities.

The article's objective is to reveal the specifics involved in applications of existing accounting techniques for recording financial flows in government institutions, and to show the relationship between accounting principles and accounting methods. This objective is achieved by solving the following problems: to reveal the content of the accounting process and its technical components; to analyze the procedural-additive approach to substantiating the essence of accounting techniques; to describe accounting techniques used for recording of financial flows in government institutions; to systematize and compare Ukrainian studies on accounting principles and accounting techniques with analogous foreign studies, to find out the scopes of adaptation of the Ukrainian law to international standards of accounting and reporting. 
The study shows that accounting techniques used in Ukraine differ from international ones where traditional accounting components have stronger analytical, statistical and econometric focus. From the comparative analysis it follows that the Ukrainian law overlooks international accounting principles of reliability and accuracy, imparity, clearness and intelligibility, relevance and uniqueness. However, these principles and techniques cannot be deemed fully applicable in the Ukrainian accounting practices unless they are scrutinized in view of the specifics involved in the Ukrainian law, economic process in Ukraine, information systems and technologies used in domestic practices of accounting.

The outlined specifics of the existing accounting techniques and relationships between accounting principles and accounting methods enable to propose the procedural-additive approach to accounting techniques used to record financial flows in government institutions, laying grounds for further improvements in the theoretical framework for accounting in government institutions.

Keywords: balance, government institution, documentation, accounting, stocktaking, calculation, evaluation, double entry, accounting methods, accounting records, financial resources.

\section{Посилання на статтю:}

Струк Н. С., Рак Г. В. Особливості застосування прийомів бухгалтерського обліку до процесу використання фінансових ресурсів у бюджетних установах // Науковий вісник Національної академії статистики, обліку та аудиту: зб. наук. пр. 2018. №1-2. C. 57-67. 